Rodzina, ekonomia i migracja. Ujęcie prawne i socjologiczno-ekonomiczne, red. Magdalena Butrymowicz, Piotr Kroczek, Kraków 2021, s. 49-79 (Biblioteczka Prawa, 4).

DOI: https://doi.org/10.15633/9788374389105.04

Paweł Ulman*

https://orcid.org/oooo-0oo2-1911-8821

UNIWERSYTET EKONOMICZNY W KRAKOWIE

Magdalena Zając

https://orcid.org/oooo-oo03-1019-4243

UNIWERSYTET EKONOMICZNY W KRAKOWIE

\title{
Gospodarstwa domowe osób starszych i ich sytuacja ekonomiczna
}

\section{Wprowadzenie}

Zanim zostanie omówiony badany problem dotyczący sytuacji ekonomicznej gospodarstw domowych osób starszych, warto powiedzieć po krótce, kim tak naprawdę jest senior. Funkcjonuje wiele definicji określających osoby starsze. Można je sklasyfikować i ograniczyć do tych o znaczeniu formalnym oraz nieformalnym ${ }^{1}$. Definicje

* Publikacja została dofinansowana ze środków subwencji przyznanej Uniwersytetowi Ekonomicznemu w Krakowie.

1 R. J. Kijak, Z. Szarota, Starość. Między diagnozq a działaniem, Warszawa 2013, s. 18. 
nieformalne starości wykorzystują zazwyczaj pojęcia, jakich używa się na co dzień w celu określenia osób starszych i są to wielokrotnie synonimy związane ze stopniem zaawansowania pewnego rodzaju niepełnosprawności, niedołężności lub niedomagania. Określa się w ten sposób osoby chore z deficytami lub wymagające opieki. Seniorem jest osoba starsza, jest to również emeryt, rencista, staruszek, osoba w wieku podeszłym lub sędziwym ${ }^{2}$. Wiek osoby starszej w Polsce nie jest określony i ujednolicony, jeżeli chodzi o przywileje i bonifikaty, z jakich senior może korzystać. Mając na uwadze ten sam brak jednolitości w krajach Unii Europejskiej, trudnością staje się rozpatrzenie wieku przyjętego za granicę początku starości. W Polsce formalnie granicę rozpoczęcia starości określa ustawa z dnia 11 września $2015 \mathrm{r}$. o osobach starszych, gdzie w artykule 4 osoba starsza jest definiowana jako osoba, która ukończyła 60 rok życia ${ }^{3}$. Według definicji proponowanej przez Światową Organizację Zdrowia [wHo] granica rozpoczęcia się wieku starszego również wynosi 60 lat. Ta sama granica przyjęta jest przez Organizację Narodów Zjednoczonych [onz] ${ }^{4}$. Natomiast, jak podaje Główny Urząd Statystyczny [GUs], zgodnie ze standardami Eurostatu oraz wytycznymi Organizacji Współpracy

2 M. Chałas, Kto to jest osoba starsza? Wystąpienie i prezentacja na konferencji "Senior to brzmi dostojnie”, 24.10.2018 r., na Wydziale Ekonomiczno-Socjologicznym Uniwersytetu Łódzkiego (https://www.google.com/url?sa=t\&rct=j\&q $=\& e s r c=s \&$ source $=$ web $\& c d=\& c a d=r j a \& u a c t=8 \& v e d=2$ ahu $=$ kewjexNPIhY_wAhxN-yoKHс9RC38Qfja AegQIAhAD\&url=https\%3A\%2F\%2Fwww.uni.lodz.pl\%2 Fplik\%2F7797\%2Fe1ea2f685f6966397a35e7e17cdo8869\&usg=AOvVawo8EPWAU xuwTuvtNinoocls); G. Kaufman, G. H. Elder, Revisiting age identity: A research note, „Journal of Aging Studies” 16 (2) (2002), s. 169-176; M. Miche, A. Brothers, M. Diehl, H. W. Wahl, The Role of Subjective Aging Within the Changing Ecologies of Aging: Perspectives for Research and Practice, „Annual Review of Gerontology \& Geriatrics" 35 (2015), s. 211-237.

3 Ustawa z dnia 11 września 2015 r. o osobach starszych, Dz. U. poz. 1705.

4 P. Kowal, J. E. Dowd, Definition of an older person. Proposed working definition of an older person in Africa for the MDS Project, http://doi.org/10.13140/2.1.5188.9286. 
Gospodarczej i Rozwoju [oEcD], osobami starszymi są osoby mające 65 i więcej lat ${ }^{5}$. Niektórzy za granicę rozpoczęcia starzenia się przyjmują wiek 50 lat, natomiast wszelkiego rodzaju zwolnienia $\mathrm{z}$ opłat, rabaty bądź bezpłatne leki są przyznawane osobom w wieku 7o+ lub 75 lat i więcej6.

Starzenie się ludności Polski to proces nieodwracalny o globalnym charakterze, mający wiele przyczyn, do których między innymi zalicza się spadek urodzeń oraz wydłużanie się przeciętnego dalszego trwania życia, jak również rozwój medycyny i wzrost świadomości w zakresie możliwości dbania o zdrowie ${ }^{7}$. Głównym miernikiem określającym poziom starości demograficznej jest udział osób starszych w ogóle populacji oraz indeks starości, który określa liczbę dziadków przypadających na 100 wnuków ${ }^{8}$. Na bazie wielu przeprowadzonych badań obserwuje się znaczny przyrost niektórych grup ludności, w tym szczególnie osób starszych. Jak podają dane statystyczne, w połowie 2018 roku liczebność Polski kształtowała się na poziomie 38413 tys.

5 GUS, Jakość życia w Polsce w 2015 r. Wyniki badania spójności społecznej, Warszawa 2017.

6 M. Chałas, Kto to jest osoba starsza?, dz. cyt.; V. F. Skirbekk, U. M. Staudinger, J. E. Cohen, How to Measure Population Aging? The Answer Is Less than Obvious, „Gerontology” 65 (2019) no. 2, s. 136-144; A. Balachandran, K. S. James, A multi-dimensional measure of population ageing accounting for Quantum and Quality in life years: An application of selected countries in Europe and Asia, „ssm Popul Health" 7 (April 2019), 100330; E. Trafiałek, Polska starość $w$ dobie przemian, Katowice 2003, s. 69-90.

7 E. Sojka, Wybrane aspekty sytuacji demograficzno-społecznej osób starszych $w$ województwie śląskim, „Studia Ekonomiczne. Zeszyty Naukowe Uniwersytetu Ekonomicznego w Katowicach" 2016 nr 286, s. 146-164; E. Frątczak, Proces starzenia się ludności Polski, „Studia Demograficzne” 2002 nr 2, s. 3-28; E. Sojka, Process of Ageing of Silesia Province Population Until 2035, „Bulletin of Geography. Socio-Economic Series" 2011 no. 16, s. 121-138.

8 Procesy demograficzne i metody ich analizy, red. J. Kurkiewicz, Kraków 2010, s. 79; GUS, Sytuacja demograficzna osób starszych i konsekwencje starzenia się ludności Polski $w$ świetle prognozy na lata 2014-2050, Warszawa 2014. 
mieszkańców, w tym osób powyżej 65 roku życia było 6619 tys., co stanowiło aż 17,2\% ludności kraju. W porównaniu do statystyk $\mathrm{z}$ roku 1990, osoby powyżej 65 lat w stosunku do całej populacji stanowiły tylko 10,2\%9. Według prognozy demograficznej dla Polski na lata 2008-2035 liczba ludności zmniejszy się z $38 \mathrm{mln}$ do $35 \mathrm{mln}$, przy jednoczesnym wzroście liczby osób powyżej 65 lat - z $5 \mathrm{mln}$ do $8 \mathrm{mln}$, czyli z $13,9 \%$ do $23,2 \%^{10}$. Natomiast przewidywane zmiany dla Polski dotyczące liczby i struktury ludności w wieku 60 i więcej lat, w perspektywie do 2050 roku, przewidują spadek liczby ludności o 4,5 mln, przy czym będzie następował systematyczny wzrost liczby osób w wieku powyżej 60 roku życia, która może osiągnąć nawet 13,7 $\mathrm{mln}^{11}$. Prognozuje się także wzrost liczby ludności powyżej 65 roku życia, której udział w miastach osiągnie 35\%, a na obszarach wiejskich przekroczy $30 \%{ }^{12}$.

Zjawisko starzenia się społeczeństwa zapoczątkowane zostało już w latach 50. i 6o. xx wieku. Zmiany demograficzne oraz wzrost liczby ludności w wieku starszym jest niejako korzystnym i pozytywnym zjawiskiem związanym ze wcześniej wspomnianym wydłużaniem się trwania życia ${ }^{13}$. Dane przedstawiają wydłużanie się przeciętnego dal-

9 Kancelaria Senatu. Biuro Analiz, Dokumentacji i Korespondencji, Aktywność osób starszych. Opracowanie tematyczne от-672, https://www.senat.gov.pl/gfx/ senat/pl/senatopracowania/17o/plik/ot-672.pdf (1.11.2019).

10 GUS, Prognoza ludności na lata 2008-2035, Warszawa 2009, s. 156; GUs, Prognoza ludności gmin na lata 2017-2030, Warszawa 2017, s. 39.

11 Ministerstwo Rodziny, Pracy i Polityki Społecznej, Informacja o sytuacji osób starszych $w$ Polsce za rok 2017, Warszawa 2018, s. 10.

12 GUS, Sytuacja demograficzna osób starszych i konsekwencje starzenia się ludności Polski w świetle prognozy na lata 2014-2050, dz. cyt., s. 34; E. Rydz, Proces starzenia się ludności w województwie pomorskim i jego społeczno-ekonomiczne konsekwencje, Słupsk-Warszawa 2012, s. 36-58.

13 S. Zrinščak, S. Lawrence, Active ageing and demographic change: challenges for social work and social policy, „European Journal of Social Work” 17 (2014) no. 3, s. $313-321$. 
szego trwania życia i tak np. dla roku 2010 wskazywano 73,3 lat dla mężczyzn i 80,6 lat dla kobiet; dla roku 2030 wartości te - według prognozy GUs sięgną: 77,6 lat - mężczyźni i 83,3 lat - kobiety, natomiast dalsze trwanie życia w Polsce w roku 2035 będzie wynosiło od 77,1 do 78 lat dla mężczyzn oraz 82,9 do 83,4 lat dla kobiet ${ }^{14}$. Takie wyniki zależne są od różnorodności poziomów życia oraz funkcjonowania systemu ochrony zdrowia i opieki nad osobami starszymi ${ }^{15}$.

Prognozy Eurostatu wskazują, że do roku 2050 w krajach Unii Europejskiej przybędzie ludności w wieku 65 lat i więcej. Wyliczenia prowadzą również do wniosków, że efektem zmian demograficznych będzie mniejsza liczba osób aktywnych zawodowo przypadających na jednego seniora. $Z$ czterech osób zmniejszy się ona do dwóch ${ }^{16}$. $\mathrm{W}$ analizach wyodrębnia się także udział osób sędziwych, tj. osób z najstarszych grup wiekowych, które notabene stanowią coraz większą grupę ludności. Te zmiany strukturalne powodują wzrost liczby ludności w wieku 60-79 lat w ogólnej liczbie ludności ${ }^{17}$. Z uwagi

14 Instytut Pracy i Spraw Socjalnych, Raport na temat sytuacji osób starszych w Polsce, oprac. zbiorowe, Warszawa 2012, s. 36; GUs, Prognoza ludności na lata 20o8-2035, dz. cyt., s. 152.

Instytut Pracy i Spraw Socjalnych, Raport na temat sytuacji osób starszych $w$ Polsce, dz. cyt., s. 173; GUS, Prognoza ludności na lata 2014-2050, Warszawa 2014, s. 25. C. Żołędowski, Starzenie się ludności - Polska na tle Unii Europejskiej, „Problemy Polityki Społecznej” 2012 nr 17, s. 29-43; R. Desjardins, The relationship between attaining formal qualifications at older ages and outcomes related to active ageing, „European Journal of Education” 54 (2019) 1, s. 30-47; R. Murkowski, Zaawansowanie procesu starzenia się populacji polski w latach 1990-2050, „Studia Oeconomica Posnaniensia” 6 (2018) nr 9, s. 59-77; A. Ochocki, Starzenie się ludności a redystrybucja dochodów, „Wiadomości Statystyczne” 64 (2019) nr 10, s. $53-62$.

17 Ministerstwo Rodziny, Pracy i Polityki Społecznej, Informacja o sytuacji osób starszych $w$ Polsce za rok 2017, dz. cyt., s. 167; Kancelaria Senatu. Biuro Analiz i Dokumentacji, Starzenie się społeczeństwa polskiego i jego skutki. Opracowanie tematyczne от-601, Warszawa 2011, s. 1; A. Warych-Juras, J. Gałka, Starzenie się ludności w polskich obszarach metropolitalnych, w: Człowiek w przestrzeni 
na podjęty temat opracowania watro wspomnieć również, że osoby starsze to osoby, które najczęściej pozostają w związku małżeńskim. Wśród osób w wieku sędziwym jest aż 2/3 osób owdowiałych, w tym aż 90\% stanowią samotnie żyjące kobiety ${ }^{18}$.

Osoby starsze, podlegając zróżnicowanym formom komunikacji we współczesnym społeczeństwie, mogą mieć niejednokrotnie problem $z$ wyrażaniem swoich zamiarów i potrzeb dostosowania się do szans, jakie tworzy aktualny rynek dóbr i usług ${ }^{19}$. Prowadzi to do tworzenia się specyficznych barier społeczno-ekonomicznych, z jakimi musi zmierzyć się gospodarka kraju. Ze względu na zmiany społeczeństwo polskie stanie przed wieloma wyzwaniami oraz potrzebą zmiany priorytetów związaną z działalnością polityki publicznej, a także koniecznością rozwoju polityki społecznej i socjalnej w celu zaspokajania potrzeb starszych osób w przyszłości. Należy ponadto nadmienić, że globalne zmiany demograficzne zachodzące w współczesnym społeczeństwie stanowią również przyczyny zmian w formowaniu się zależności rodzinnych oraz wpływają na jej wewnętrzne funkcjonowanie, co oznacza, że wzrost liczby ludności w wieku starszym prowadzi do konieczności dostosowania się gospodarki kraju do realizacji wszelkich przedsięwzięć skierowanych właśnie do tej grupy wiekowej ${ }^{20}$.

zurbanizowanej, red. M. Soja, A. Zborowski, Kraków 2011, s. 99-110; G. Trzpiot, J. Szołtysek, Starzenie się funkcjonalnych grup wieku a kapitał społeczny, „Ekonometria" $2017 \mathrm{nr}$ 2, s. 9-17; P. Szukalski, Starzenie się ludności miast wojewódzkich - przeszłość, teraźniejszość, przyszłość, „Demografia i Gerontologia Społeczna - Biuletyn Informacyjny” $2017 \mathrm{nr}$ 12, s. 1-5.

18 Ministerstwo Rodziny, Pracy i Polityki Społecznej, Informacja o sytuacji osób starszych $w$ Polsce za rok 2017, dz. cyt., s. 9; A. Kotlarska-Michalska, Starość w aspekcie socjologicznym, „Roczniki Socjologii Rodziny” 12 (2000), s. 147-158.

19 H. Zielińska-Więczkowska, K. Kędziora-Kornatowska, T. Kornatowski, Starość jako wyzwanie, „Gerontologia Polska” 2008 nr 3, s. 131-136.

20 E. Trafiałek, Kapitał społeczny w starzejącym się społeczeństwie, „EXLIBRIs Biblioteka Gerontologii Społecznej”/„Polish Social Gerontology Journal” 14 (2017) 
Konsekwencje tych zmian związane będą głównie z problemem: (1) zapewnienia opieki medycznej, (2) funkcjonowania opieki i pomocy społecznej, (3) podtrzymania aktywności i aktywizacji osób starszych i zainicjowania odpowiednich programów w tym zakresie, (4) poniesienia kosztów oraz wydatków na zaspokojenie świadczeń kierowanych do grupy potrzebujących ${ }^{21}$.

Następstwem wynikającym z powiększania się grupy seniorów będzie wzrost zapotrzebowania na opiekę zdrowotną, w tym ambulatoryjną opiekę zdrowotną, w ramach której najważniejsze są porady lekarskie w zakresie podstawowej i specjalistycznej opieki oraz porady stomatologiczne $\mathrm{w}$ przychodniach oferowane stricte dla seniorów. Coraz bardziej narasta potrzeba rozwoju i wzrostu dostępności do opieki geriatrycznej, czyli tworzenia stacjonarnych oddziałów szpitalnych zapewniających kompleksową opiekę medyczną oraz usługi pielęgnacyjne skierowane do osób w podeszłym wieku. Wiąże się to również z rozwojem stacjonarnych zakładów opieki długoterminowej, hospicyjnej i paliatywnej ${ }^{22}$. W ramach sprawowanej opieki warto wymienić również leczenie uzdrowiskowe, które kierowane jest do zróżnicowanych grup wiekowych, niemniej jednak

nr 2, s. 18-20, 27-28; G. Trzpiot, Prognozy ludności dla Polski - perspektywa logistyki społecznej, Katowice 2013, s. 70-91; wHо, Health and ageing. A discussion paper, https://apps.who.int/iris/bitstream/handle/10665/66682/WHO_NMH_ HPS_01.1.pdf? sequence $=1$ \&isAllowed $=y(1.11 .2019)$.

21 A. Więcek, M. Mossakowska, P. Błędowski, Aspekty medyczne, psychologiczne, socjologiczne i ekonomiczne starzenia się ludności w Polsce, Poznań 2012, s. 407; B. Szopa, Konsekwencje procesu starzenia się społeczeństwa. Wybrane problemy, „Problemy Zarządzania” 14 (2016) nr 2 (59) t. 1, s. 24-38; A. Przybyłka, Świadczenia dla osób starszych $i$ niepelnosprawnych $w$ ramach systemów ochrony zdrowia i pomocy społecznej (wybrane zagadnienia), „Acta Universitatis Lodziensis. Folia Oeconomica" 2013 nr 297, s. 183-19o.

22 Ministerstwo Rodziny, Pracy i Polityki Społecznej, Informacja o sytuacji osób starszych $w$ Polsce za rok 2017, dz. cyt., s. 91. 
osoby starsze są częstszymi beneficjentami wyżej wymienionych świadczeń.

W najbliższym czasie powinno się określić możliwości wykształcenia zarówno kadry medycznej składającej się z lekarzy opiekujących się i udzielających pomocy osobom starszym, jak i ratowników medycznych, którzy znacznie częściej udzielają pomocy osobom w wieku powyżej 65 roku życia. Kolejną grupą zawodową, istotną z punktu widzenia opieki nad seniorem, są pielęgniarki koordynujące opiekę nad tą osobą, sprawujące pomoc w miejscu zamieszkania, ordynujące leki ${ }^{23}$. Ważnym zawodem, na który wzrasta popyt na współczesnym rynku pracy, jest między innymi opiekun medyczny sprawujący opiekę nad osobami starszymi. Kształcenie odpowiedniej liczby osób w tym kierunku pozwoli zdjąć wiele obowiązków z personelu medycznego. Opiekun medyczny jest to osoba o odpowiednich kwalifikacjach medycznych uprawniona do sprawowania podstawowej pielęgnacji, pomocy i utrzymania sprawności zarówno fizycznej, jak i aktywności społecznej osoby starszej. Wyzwaniem jest analiza potrzeb i kosztów realizacji w odniesieniu do wielkości personelu i opiekunów, którzy będą sprawować odpowiednią i wystraczającą opiekę nad seniorami.

Kolejnym zadaniem staje się zagwarantowanie pomocy społecznej oraz opieka nad osobami starszymi, tak jak wynika to z ustawy o pomocy społecznej i aktów wykonawczych do tej ustawy. Wraz ze wzrostem liczby ludności w wieku starszym zmieniają się potrzeby społeczne, a ich zaspokojenie w zakresie grupy seniorów realizowane jest w formach (1) świadczeń pieniężnych, (2) świadczeń niepieniężnych i (3) możliwości skorzystania z programów rządowych służących

23 Ministerstwo Rodziny, Pracy i Polityki Społecznej, Informacja o sytuacji osób starszych $w$ Polsce za rok 2017, dz. cyt., s. 34; J. Kujawska, Organizacja i zarzadzanie opieka nad osobami starszymi, „Zeszyty Naukowe Uniwersytetu Szczecińskiego. Finanse, Rynki Finansowe, Ubezpieczenia” 1 (2015) nr 74, s. 709-720. 
osobom starszym²4. Dodatkowe środki pieniężne, z których mogą korzystać osoby starsze, są wypłacane przez zus. Prócz emerytur stanowiących zazwyczaj główne źródło utrzymania, funkcjonują również renty związane $z$ niezdolnością do pracy oraz renty rodzinne, jak również renty socjalne. Istnieje ponadto szereg świadczeń dla osób niesamodzielnych, świadczeń przedemerytalnych oraz różnego rodzaju dodatki²5. Osoby starsze najczęściej korzystają ze świadczeń pielęgnacyjnych, rodzinnych i zasiłków rehabilitacyjnych lub pogrzebowych $^{26}$. Zmianie ulegają także świadczenia, na które mogą liczyć osoby starsze, a są to zasiłki stałe, okresowe i celowe. Wraz ze wzrostem liczby ludności w starszym wieku wzrośnie liczba wypłacanych świadczeń, co może w przyszłości spowodować zmniejszenie się kwot wypłacanych poszczególnym osobom. Dochody, jakie zasilają salda seniorów, zależą również od ich indywidualnych decyzji pozostania na rynku pracy oraz wielkości oszczędności skumulowanych przez kolejne lata życia i czas świadczenia pracy. Dochody z najmu, dochody ze świadczeń jednorazowych lub otrzymywanych krócej niż przez okres jednego roku, dochody z pracy na własny rachunek, z pracy

24 T. Karkowski, Dostosowywanie zasobów kadry medycznej do potrzeb starzejącego się społeczeństwa, „Zdrowie Publiczne i Zarządzanie” 13 (2015) nr 1, s. 82-94.

25 zUs, Ustalanie uprawnień do świadczeń, https://www.zus.pl/ustalanie-uprawnien-do-swiadczen (1.11.2019).

26 Informator prawny, https://www.infor.pl/prawo/emerytury/ (1.11.2019); M. Góra, Thinking About Pension Systems for the 21st Century: A Few Remarks Based on the Polish Example, „CASE Research Paper” 2018 no. 154, s. 17; zUs, 50o+ dla osób niezdolnych do samodzielnej egzystencji - najczęściej zadawane pytania, https://www. zus.pl/baza-wiedzy/biezace-wyjasnienia-komorek-merytorycznych/swiadczenia/50o-dla-osob-niezdolnych-do-samodzielnej-egzystencji-najczesciej-zadawane-pytania (1.11.2019); GUS, Sytuacja gospodarstw domowych w 2018 r. ws świetle wyników badania budżetów gospodarstw domowych, https://stat.gov.pl/obszary-tematyczne/warunki-zycia/dochody-wydatki-i-warunki-zycia-ludnosci/sytuacja-gospodarstw-domowych-w-2018-r-w-swietle-wynikow-badania-budzetow-gospodarstw-domowych,3,18.html (1.11.2019). 
dorywczej oraz rolnictwa także kształtują ostateczną kwotę, jaką badana grupa wiekowa dysponuje ${ }^{27}$.

Do świadczeń niepieniężnych zalicza się w szczególności usługi opiekuńcze i specjalistyczne, o których wspomniano powyżej, tak jak i te, które są świadczone w miejscu zamieszkania osób starszych. Należą do nich usługi świadczone w ośrodkach wsparcia lub całodobowe usługi świadczone $\mathrm{w}$ rodzinnym domu pomocy albo $\mathrm{w}$ domu pomocy społecznej. Osoby starsze mogą również skorzystać z placówek zapewniających całodobową opiekę nad osobami niepełnosprawnym czy przewlekle chorymi ${ }^{28}$. W ramach pomocy powstaje wiele nowych programów rządowych, związanych nie tylko z opieką nad osobami sędziwymi, ale i wsparciem żywnościowym oraz tworzeniem jednostek pomocowych i zapewniających rozrywkę i możliwość spędzania czasu wolnego. Wraz ze wzrostem liczby ludności starszej zapotrzebowanie na tego typu przedsięwzięcia będzie wzrastać i będzie nasilać się potrzeba stworzenia nowych atrakcyjnych ofert, o wyższych standardach i poziomie realizacji celów. Konsekwencją jest wzrost liczby miejsc pracy, co wiąże się z potrzebami zapewnienia środków finansowych na zatrudnienie wykwalifikowanej obsługi ${ }^{29}$.

Istotną rolę w zakresie opieki nad osobami starszymi pełnią również ośrodki: pomocy społecznej, powiatowe centra pomocy rodzinie

27 L. Morawski, Źródła dochodów i zamożności emerytów na tle innych grup wiekowych, w: G. Bukowska, G. Kula, L. Morawski, Ryzyko ubóstwa osób starszych, Warszawa 2011, s. 135; J. Czapiński, P. Błędowski, Aktywność społeczna osób starszych w kontekście percepcji Polaków. Diagnoza społeczna 2013. Raport tematyczny, Warszawa 2014, s. 9-31.

28 Ministerstwo Rodziny, Pracy i Polityki Społecznej, Informacja o sytuacji osób starszych $w$ Polsce za rok 2017, dz. cyt., s. 18.

29 J. Niedbalski, Kultura organizacyjna państwowych instytucji opiekuńczych na przykładzie domów pomocy społecznej dla osób starszych, „Przedsiębiorczość i Zarządzanie" 19 (2018) z. 11 cz. 2, s. 423-437. 
świadczące zadania z zakresu usług opiekuńczych itp., które swoją działalnością obejmują coraz więcej osób potrzebujących.

Zmianom podlega też sytuacja na rynku pracy i aktywność zawodowa osób starszych. Osoby aktywne zawodowo w wieku powyżej 6o roku życia stanowią mniej więcej około 7,3\% ogółu aktywnych zawodowo. Znacznie więcej aktywnych zawodowo jest nadal mężczyzn niż kobiet ${ }^{30}$.

\section{Dane statystyczne i wyniki badania empirycznego}

W celu analizy sytuacji ekonomicznej gospodarstw domowych wykorzystano dane z Badania budżetów gospodarstw domowych (BBGD). Jest ono jednym $z$ najważniejszych badań reprezentacyjnych przeprowadzanych przez Gus. Głównym celem tego badania jest rejestracja poziomu dochodów i ich źródeł oraz poziomu wydatków i ich rodzajów w polskich gospodarstwach domowych. W okresie od 1957 roku, od kiedy w sposób nieprzerwany в BGD jest w Polsce przeprowadzane, ten główny cel jest realizowany, chociaż zmieniała się metoda badania, zakres zbiorowości gospodarstw domowych oraz sam zakres merytoryczny badania. Obecnie pozyskuje się dane nie tylko o dochodach i wydatkach, ale również o strukturze demograficznej gospodarstwa domowego, spożyciu podstawowych artykułów żywnościowych, wyposażeniu gospodarstw domowych w dobra trwałego użytku, sytuacji mieszkaniowej oraz subiektywnie

30 Ministerstwo Rodziny, Pracy i Polityki Społecznej, Informacja o sytuacji osób starszych $w$ Polsce za rok 2017, dz. cyt., s. 24; E. Antczak, K. Lewandowska-Gwarda, Dynamika procesu starzenia się ludności w Polsce. Ocena z wykorzystaniem metod strukturalno-geograficznych, „Studia Regionalne i Lokalne” 2018 nr 4 (74), s. $89-110$. 
ocenianej sytuacji materialnej. Wspomniane obszary badania pozwalają na wieloaspektową analizę sytuacji ekonomicznej gospodarstw domowych różnych grup społecznych, w tym gospodarstw domowych osób starszych.

Jak już wcześniej zostało wspomniane, jako osoby starsze będą rozumiane osoby w wieku co najmniej 6o lat. W zasadniczej części prezentacji wyników analizy empirycznej posłużono się indywidualnymi danymi z 2018 roku, selekcjonując je w taki sposób, aby badaniu poddane zostały jedynie osoby w wieku co najmniej 6o lat $\mathrm{i}$ ich gospodarstwa domowe. Tak więc dane o dochodach i wydatkach zostały przeliczone na osobę (podzielone przez liczbę osób w gospodarstwie domowym) i odnoszą się do gospodarstwa domowego osoby starszej. Takie podejście jest uzasadnione tym, że w BBGD wydatki, jak również niektóre kategorie dochodów odnosi się do całości gospodarstwa domowego (nie rozdziela się na poszczególnych członków gospodarstwa domowego). Ponadto bardziej nas interesuje sytuacja ekonomiczna gospodarstw domowych ${ }^{31}$, w których żyją starsi ludzie, a nie jedynie ich indywidualne dochody czy wydatki, które są składową budżetu całego ich gospodarstwa domowego.

Zanim przedstawione zostaną zapowiadane wyżej wyniki analizy sytuacji ekonomicznej gospodarstw osób starszych w 2018 roku poniżej zaprezentujemy dynamikę dochodów i wydatków gospodarstw domowych, których głównym źródłem utrzymania jest emerytura. Odpowiednie dane zaczerpnięto z kolejnych publikacji Gus (Budżety gospodarstw domowych), w których nie pokazuje się dochodów i wydatków gospodarstw domowych osób starszych rozumianych jako jedna z grup społecznych. Najbliższą kategorią obejmującą

31 Należy mieć również na uwadze, że gospodarstwo domowe jest definiowane przezGus jako grupa osób wspólnie mieszkających i wspólnie się utrzymujących (GUs, Zeszyt metodologiczny. Badanie budżetów gospodarstw domowych, Warszawa 2018, s. 269). 
w zasadniczej części gospodarstwa osób starszych są gospodarstwa utrzymujące się głównie z emerytury, co nie wyklucza sytuacji, że $\mathrm{w}$ takim gospodarstwie nie ma osoby w wieku 60 lat i więcej (np. z powodu uzyskania prawa do emerytury w wieku niższym niż 6o lat), chociaż taka sytuacja powinna występować raczej rzadko.

Wykres 1 prezentuje zmiany przeciętnego poziomu dochodów na osobę oraz emerytur na osobę w gospodarstwach, w których głównym źródłem utrzymania jest emerytura oraz w gospodarstwach jednoosobowych tego typu. $W$ tym drugim przypadku niewątpliwie badana osoba jest emerytem.

Wykres 1. Dynamika przeciętnych dochodów ogółem oraz emerytur krajowych na osobę w gospodarstwach domowych $\mathrm{z}$ emeryturą jako głównym źródle utrzymania

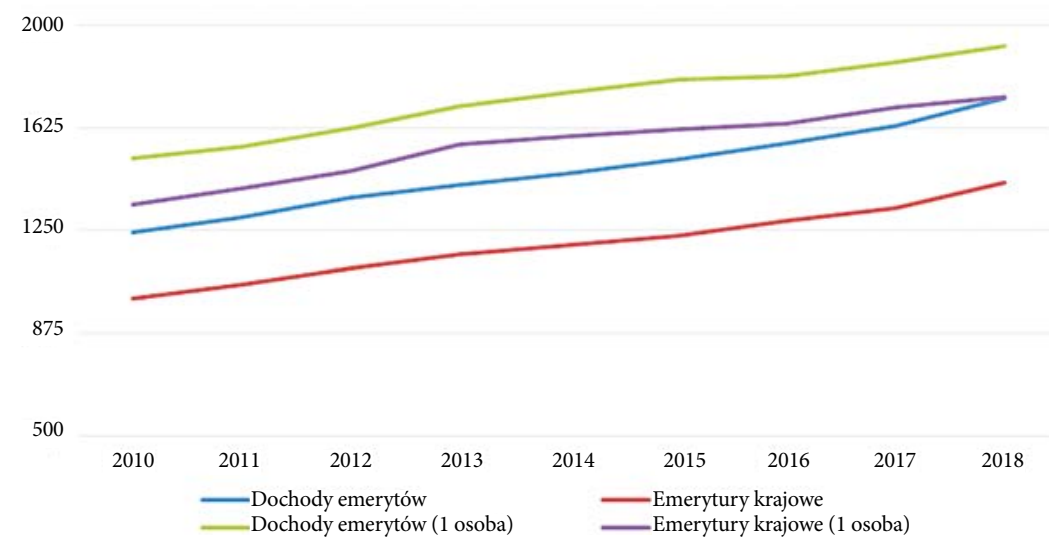

Źródło: opracowanie własne na podstawie вBGD (kolejne lata od 2011 do 2019).

Wszystkie kategorie dochodów wykazały dynamiczny wzrost w badanym okresie 9 lat. Emerytury krajowe w jednoosobowych gospodarstwach emerytów charakteryzują się największą przeciętną wartością spośród badanych kategorii dochodów i wzrosły z poziomu 1343,77 zł w 2009 roku do poziomu 1735,79 zł, czyli o ponad 29\%. Podobne 
przyrosty można odnotować w przypadku pozostałych prezentowanych typów dochodów. Warto zwrócić uwagę na różnicę między poziomem dochodów ogółem w jednoosobowych gospodarstwach emerytów a poziomem emerytur krajowych w tych gospodarstwach. Wskazuje ona na wielkość innych dochodów niż emerytury w budżecie domowym tych gospodarstw. Stanowią one ok. 10\% ogółu dochodów.

Na wykresie 2 i 3 zaprezentowane zostały struktury wybranych grup wydatków w gospodarstwach utrzymujących się przede wszystkim $\mathrm{z}$ emerytury oraz jednoosobowych gospodarstw emeryckich.

Wykres 2. Struktura wydatków w gospodarstwach domowych, w których głównym źródłem utrzymania jest emerytura - okres 2010-2018

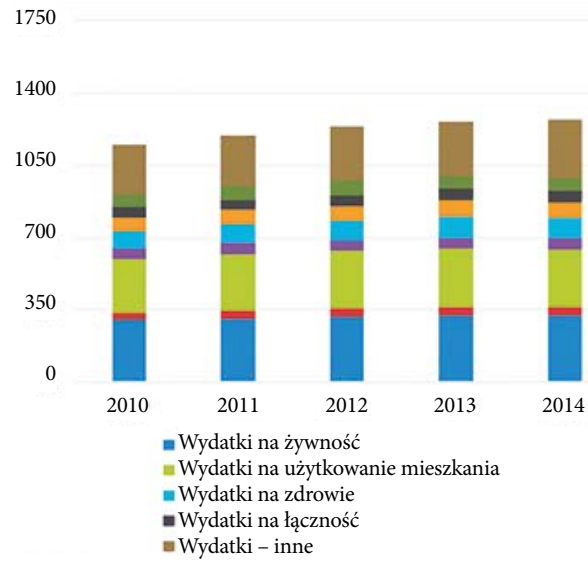

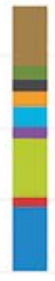

2015

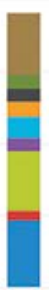

2016

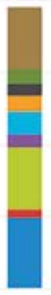

2017

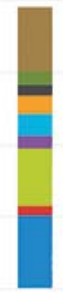

2018

= Wydatki na odzież i obuwie

= Wydatki na wyposażenie mieszkania

= Wydatki na transport

" Wydatki na rekreację i kulturę

Źródło: opracowanie własne na podstawie BBGD (kolejne lata od 2011 do 2019). 
Wykres 3. Struktura wydatków w gospodarstwach domowych jednoosobowych, w których głównym źródłem utrzymania jest emerytura - okres 2010-2018

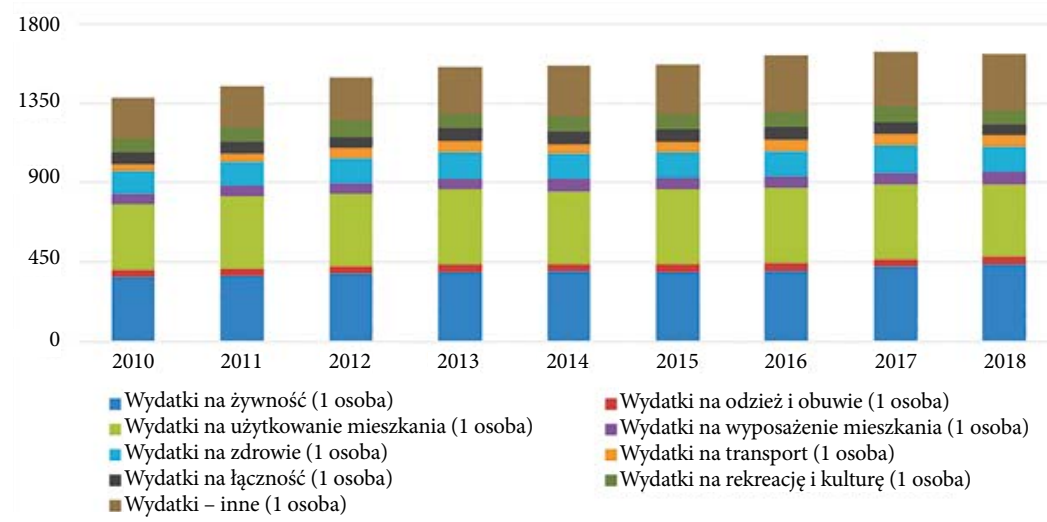

Źródło: opracowanie własne na podstawie вBGD (kolejne lata od 2011 do 2019).

W jednym i drugim przypadku obserwuje się wzrost wydatków ogółem w badanych gospodarstwach domowych w latach 2010-2018. W przypadku wieloosobowych gospodarstw wzrost ten wyniósł ok. 19,5\%, a w przypadku gospodarstw jednoosobowych ok. 18,3\%. Porównując ten wynik z przyrostem dochodów, możemy zauważyć, że jest on niższy o ok. 10 punktów procentowych, co z kolei wskazuje na wzrost możliwości oszczędzania części dochodu w przypadku przeciętnego (statystycznego) gospodarstwa domowego osób utrzymujących się głównie $\mathrm{z}$ emerytury. Znaczącym udziałem w wydatkach ogółem badanych gospodarstw charakteryzują się wydatki na żywność (ok. 27-28\%), użytkowanie mieszkania (ok. 21-25\%) i wydatki na zdrowie (ok. 8-9\%). W związku z tym, że udział wydatków na żywność można traktować jako wskaźnik zamożności gospodarstwa domowego, co wynika z niskiej elastyczności dochodowej tych wydatków, powodującej wzrost wartości tego wskaźnika w sytuacji spadku dochodów (a więc i spadku wydatków ogółem), 
na wykresie 4 pokazane zostało kształtowanie się tego udziału w badanym okresie 9 lat.

Wykres 4. Udział wydatków żywnościowych w wydatkach ogółem dla gospodarstw domowych, w których głównym źródłem utrzymania są dochody z emerytury w latach 2010-2018 - gospodarstwa wieloosobowe i jednoosobowe

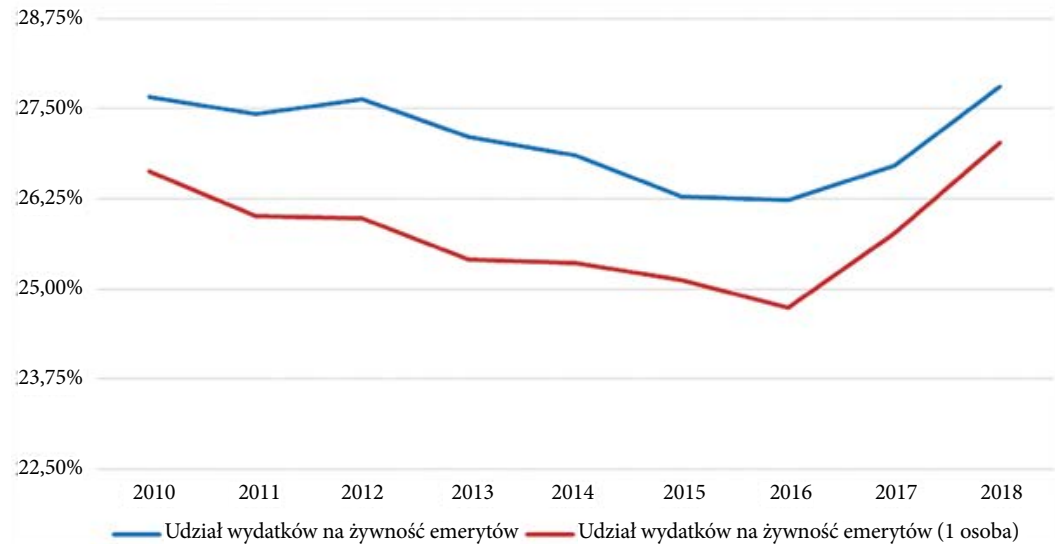

Źródło: obliczenia własne na podstawie B BGD (kolejne lata od 2011 do 2019).

W latach od 2010-2016 zasadniczo udział wydatków na żywność w wydatkach ogółem badanych gospodarstw wykazywał tendencję malejącą $z$ poziomu ok. 26,5-27,5\% do poziomu 24,7-26,3\%, po czym nastąpił wzrost do poziomu ok. 27-28\%. Wzrost ten może wynikać ze wzrostu cen żywności obserwowanych w ostatnich latach przy proporcjonalnie mniejszym przyroście kwoty wydatków ogółem.

W dalszej części zaprezentowane zostaną wyniki analizy statystycznej dla gospodarstw domowych osób w wieku co najmniej 6o lat, dokonane na bazie indywidualnych danych z BBGD za 2018 roku. W kolejnych tabelach 1-6 przedstawione zostały struktury osób starszych ze względu na wybrane cechy społeczno-ekonomiczne. 
Tabela 1. Struktura terytorialnego rozmieszczenia osób starszych w układzie województw w Polsce w 2018 roku

\begin{tabular}{|c|c|c|c|}
\hline Województwo & Udział (w \%) & Województwo & Udział (w \%) \\
\hline dolnośląskie & 7,64 & podkarpackie & 5,47 \\
\hline kujawsko-pomorskie & 5,28 & podlaskie & 5,21 \\
\hline lubelskie & 6,12 & pomorskie & 11,78 \\
\hline lubuskie & 2,42 & śląskie & 3,56 \\
\hline lódzkie & 6,94 & świętokrzyskie & 3,38 \\
\hline małopolskie & 8,73 & warmińsko-mazurskie & 9,02 \\
\hline mazowieckie & 13,42 & wielkopolskie & 4,63 \\
\hline opolskie & 2,86 & zachodniopomorskie & \\
\hline
\end{tabular}

Źródło: obliczenia własne na podstawie danych B BGD z 2018 roku.

Tabela 2. Struktura osób starszych w układzie ze względu na główne źródło utrzymania w Polsce w 2018 roku

\begin{tabular}{|c|c|c|c|}
\hline Główne źródło utrzymania & Udział (w \%) & Główne źródło utrzymania & Udział (w \%) \\
\hline $\begin{array}{c}\text { praca najemna na stanowisku } \\
\text { robotniczym }\end{array}$ & 11,17 & emerytura & 64,34 \\
\hline $\begin{array}{c}\text { praca najemna na stanowisku } \\
\text { nierobotniczym }\end{array}$ & 10,14 & renta & 6,31 \\
\hline użytkowanie gospodarstwa rolnego & 3,89 & świadczenia pozostałe & 0,93 \\
\hline $\begin{array}{l}\text { praca na własny rachunek poza } \\
\text { gospodarstwem rolnym w użytkowaniu } \\
\text { indywidualnym, wykonywanie wolnego } \\
\text { zawodu }\end{array}$ & 2,88 & $\begin{array}{l}\text { dary, alimenty i pozostałe } \\
\text { dochody }\end{array}$ & 0,11 \\
\hline własność & 0,17 & inne przychody & 0,08 \\
\hline
\end{tabular}

Źródło: obliczenia własne na podstawie danych B BGD z 2018 roku. 
Tabela 3. Struktura osób starszych w układzie ze względu na klasę miejscowości zamieszkania w Polsce w 2018 roku

\begin{tabular}{|c|c|c|c|}
\hline Klasa miejscowości & Udział $(\mathbf{w} \%)$ & Klasa miejscowości & Udział (w \%) \\
\hline 500 tys. mieszkańców i więcej & 12,17 & $20-99$ tys. mieszkańców & 20,69 \\
\hline 200-499 tys. mieszkańców & 9,41 & poniżej 20 tys. mieszkańców & 13,60 \\
\hline $100-199$ tys. mieszkańców & 8,97 & wieś & 35,16 \\
\hline
\end{tabular}

Źródło: obliczenia własne na podstawie danych B BGD z 2018 roku.

Tabela 4. Struktura osób starszych w układzie ze względu na typ biologiczny gospodarstwa w Polsce w 2018 roku

\begin{tabular}{|c|c|c|c|}
\hline Typ gospodarstwa & Udział (w \%) & Typ gospodarstwa & Udział (w \%) \\
\hline małżeństwo bez dzieci & 38,10 & $\begin{array}{c}\text { małżeństwo z przynajmniej } \\
\text { I dzieckiem na utrzymaniu i innymi } \\
\text { osobami }\end{array}$ & 10,49 \\
\hline $\begin{array}{l}\text { małżeństwo z } 1 \text { dzieckiem } \\
\text { na utrzymaniu }\end{array}$ & 0,94 & $\begin{array}{l}\text { matka z dziećmi na utrzymaniu } \\
\text { i innymi osobami }\end{array}$ & 2,18 \\
\hline małżeństwo z 2 dzieci na utrzymaniu & 0,09 & $\begin{array}{c}\text { ojciec z dziećmi na utrzymaniu } \\
\text { i innymi osobami }\end{array}$ & 0,29 \\
\hline małżeństwo z 3 dzieci na utrzymaniu & 0,01 & inne osoby z dziećmi na utrzymaniu & 0,99 \\
\hline $\begin{array}{l}\text { małżeństwo z } 4 \text { (i więcej) dzieci } \\
\text { na utrzymaniu }\end{array}$ & 0,01 & gospodarstwa jednoosobowe & 23,71 \\
\hline matka z dziećmi na utrzymaniu & 0,03 & pozostałe & 23,15 \\
\hline ojciec z dziećmi na utrzymaniu & 0,01 & $\mathrm{x}$ & $\mathrm{x}$ \\
\hline
\end{tabular}

Źródło: obliczenia własne na podstawie danych B BGD z 2018 roku. 
Tabela 5. Struktura osób starszych w układzie ze względu na liczbę osób w gospodarstwie i stan cywilny w Polsce w 2018 roku

\begin{tabular}{|c|c|c|c|}
\hline Liczba osób w gospodarstwie & Udział (w \%) & Stan cywilny & Udział (w \%) \\
\hline 1 & 23,71 & kawaler, panna & 4,03 \\
\hline 2 & 43,31 & żonaty, zamężna & 59,90 \\
\hline 3 & 14,81 & wdowiec, wdowa & 30,81 \\
\hline 4 & 5,84 & rozwiedziony, rozwiedziona & 4,74 \\
\hline 5 i więcej & 12,33 & w separacji & 0,52 \\
\hline
\end{tabular}

Źródło: obliczenia własne na podstawie danych B BGD z 2018 roku.

Tabela 6. Struktura osób starszych w układzie ze względu na wykształcenie i płeć w Polsce w 2018 roku

\begin{tabular}{|c|c|c|c|}
\hline Poziom wykształcenia & Udział $(\mathbf{w} \%)$ & Płeć & Udział (w \%) \\
\hline co najwyżej gimnazjalne & 24,62 & mężczyzna & 41,26 \\
\hline zasadnicze zawodowe & 29,45 & kobieta & 58,74 \\
\hline średnie & 32,85 & $\mathrm{x}$ & $\mathrm{x}$ \\
\hline wyższe & 13,08 & $\mathrm{x}$ & $\mathrm{x}$ \\
\hline
\end{tabular}

Źródło: obliczenia własne na podstawie danych B BGD z 2018 roku.

Charakteryzując pokrótce badaną zbiorowość osób starszych, można stwierdzić, że najczęściej zamieszkują one województwo mazowieckie i śląskie, a najrzadziej lubuskie i opolskie, co jest zasadniczo zgodne z terytorialnym rozkładem ludności ogółem w Polsce. W zdecydowanej większości głównym źródłem utrzymania gospodarstw domowych osób starszych jest emerytura, natomiast praca najemna stanowi główne źródło utrzymania gospodarstwa dla nieco ponad $20 \%$ osób. Najczęściej osoby starsze mieszkają na wsi i w małych miastach, tworząc gospodarstwa małżeństw bez dzieci na utrzymaniu 
oraz gospodarstwa osób samotnych. Wśród osób starszych przeważają te, które żyją w związku małżeńskim. Znaczny udział stanowią także osoby samotne $z$ powodu śmierci współmałżonka. Osoby starsze charakteryzują się raczej niższym poziomem wykształcenia - ponad połowa $\mathrm{z}$ nich ma wykształcenie co najwyżej zasadnicze zawodowe. W badanej grupie przeważają kobiety.

W kolejne części niniejszego opracowania przedstawione zostaną przeciętne wartości dochodów na osobę oraz wydatków na osobę ogółem, jak również dla wybranych grup wydatków. Wspomniane kategorie ekonomiczne obliczono dla gospodarstw osób starszych w większości przekrojów prezentowanych w tabelach 1-6. W tabeli 7 pokazano więc, jak kształtują się dochody i wydatki na osobę gospodarstw osób starszych w przekroju ze względu na województwa.

Tabela 7. Dochody i wydatki gospodarstw domowych osób starszych w 2018 roku w układzie województw

\begin{tabular}{|c|c|c|c|c|c|c|c|c|c|}
\hline \multirow[b]{2}{*}{ 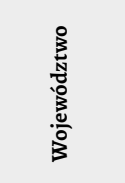 } & \multirow{2}{*}{ 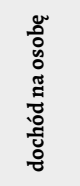 } & \multicolumn{8}{|c|}{ Wydatki na osobę } \\
\hline & & 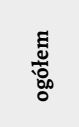 & 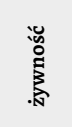 & 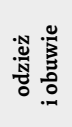 & 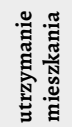 & $\begin{array}{l}\frac{\pi}{3} \\
\frac{0}{3} \\
\end{array}$ & 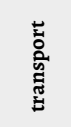 & 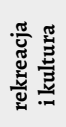 & 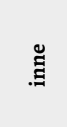 \\
\hline dolnośląskie & 1852,67 & 1394,08 & 364,65 & 41,28 & 291,22 & 105,82 & 98,16 & 54,81 & 438,13 \\
\hline $\begin{array}{l}\text { kujawsko- } \\
\text {-pomorskie }\end{array}$ & 1726,43 & 1328,73 & 361,73 & 44,00 & 271,15 & 100,72 & 115,63 & 55,05 & 380,44 \\
\hline lubelskie & 1695,71 & 1210,32 & 340,33 & 45,07 & 222,34 & 93,38 & 100,87 & 46,50 & 361,85 \\
\hline lubuskie & 1852,43 & 1342,64 & 374,97 & 33,35 & 289,93 & 99,83 & 84,97 & 52,73 & 406,87 \\
\hline łódzkie & 1727,08 & 1348,57 & 354,20 & 46,00 & 270,73 & 122,47 & 96,49 & 49,36 & 409,32 \\
\hline małopolskie & 1741,71 & 1140,70 & 341,52 & 40,38 & 269,88 & 87,10 & 68,37 & 39,36 & 294,09 \\
\hline mazowieckie & 2087,18 & 1533,57 & 386,80 & 51,43 & 297,76 & 130,02 & 142,84 & 52,13 & 472,58 \\
\hline
\end{tabular}




\begin{tabular}{|c|c|c|c|c|c|c|c|c|c|}
\hline \multirow{2}{*}{\begin{tabular}{l}
0 \\
\multirow{3}{*}{} \\
0 \\
0 \\
0 \\
0 \\
0 \\
3 \\
3
\end{tabular}} & \multirow{2}{*}{ 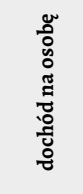 } & \multicolumn{8}{|c|}{ Wydatki na osobę } \\
\hline & & $\frac{\Xi}{0}$ & 瓷 & 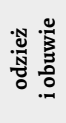 & 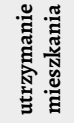 & $\frac{0}{0}$ & 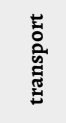 & 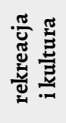 & 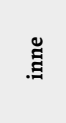 \\
\hline podkarpackie & 1518,68 & 1065,85 & 328,14 & 39,66 & 215,25 & 74,09 & 72,92 & 41,39 & 294,39 \\
\hline podlaskie & 1647,83 & 1161,12 & 367,34 & 34,94 & 229,47 & 72,31 & 121,64 & 42,68 & 292,74 \\
\hline pomorskie & 1847,55 & 1418,44 & 385,92 & 47,85 & 293,56 & 120,93 & 80,03 & 63,49 & 426,67 \\
\hline śląskie & 2030,99 & 1498,97 & 381,34 & 44,12 & 331,36 & 114,11 & 110,71 & 50,21 & 467,12 \\
\hline świętokrzyskie & 1715,13 & 1276,31 & 366,68 & 41,95 & 293,31 & 102,59 & 108,39 & 35,82 & 327,58 \\
\hline $\begin{array}{l}\text { warmińsko- } \\
\text {-mazurskie }\end{array}$ & 1709,73 & 1128,35 & 347,18 & 38,54 & 250,57 & 83,60 & 65,47 & 44,31 & 298,69 \\
\hline wielkopolskie & 1740,36 & 1145,41 & 320,34 & 37,88 & 264,04 & 86,19 & 75,84 & 48,19 & 312,94 \\
\hline $\begin{array}{l}\text { zachodnio- } \\
\text { pomorskie }\end{array}$ & 1871,94 & 1375,66 & 377,38 & 46,66 & 299,00 & 84,89 & 108,99 & 56,70 & 402,02 \\
\hline Ogół & 1825,33 & 1322,71 & 360,61 & 43,39 & 277,63 & 102,73 & 99,55 & 49,35 & 389,45 \\
\hline
\end{tabular}

Źródło: obliczenia własne na podstawie danych в BGD z 2018 roku.

Zdecydowanie najlepszą sytuację ekonomiczną obserwujemy w gospodarstwach osób starszych zamieszkujących województwo mazowieckie i śląskie, natomiast najniższymi wartościami przeciętnych dochodów i wydatków charakteryzują się gospodarstwa w województwie podkarpackim. W związku z relatywnie niskimi wydatkami na żywność w województwie wielkopolskim zaobserwowano tam najniższą wartość udziału wydatków żywnościowych w wydatkach ogółem (ok. 23\%), natomiast najwyższą w województwie mazowieckim (blisko $28 \%$ ). Pomimo więc relatywnie wysokich dochodów w tym województwie okazuje się, że - być może z powodu wysokich cen produktów i usług - wydatki na zaspokojenie odpowiednich potrzeb 
są również wysokie, co nie jest oczywiście równoznaczne z lepszą sytuacją ekonomiczną gospodarstw osób starszych zamieszkujących województwo mazowieckie. Trzeba też mieć na uwadze, że zbiorowość osób zamieszkujących to województwo jest dość różna, w zależności czy zamieszkują w Warszawie lub jej okolicach czy w innych rejonach województwa mazowieckiego. Warto również zwrócić uwagę na relatywnie duże zróżnicowanie terytorialne wydatków na zdrowie i transport. W niektórych województwach przeciętny poziom tych wydatków jest dwa razy większy od ich najniższego poziomu. Z powyższego wynika, że istnieje terytorialne zróżnicowanie poziomu dochodów i wydatków w gospodarstwach osób starszych, które z jednej strony może być spowodowane poziomem rozwoju społeczno-ekonomicznego poszczególnych regionów Polski, a z drugiej - w przypadku wydatków - zróżnicowaniem cen.

W tabeli 8 zaprezentowano, w analogicznym układzie jak wyżej, dochody i wydatki gospodarstw osób starszych w podziale ze względu na wybrane główne źródła utrzymania gospodarstwa domowego. Wzięto pod uwagę jedynie te kategorie źródeł utrzymania, dla których w tabeli 2 zaobserwowano udziały większe niż $1 \%$.

Tabela 8. Dochody i wydatki gospodarstw domowych osób starszych w 2018 roku w układzie ze względu na wybrane główne źródło utrzymania

\begin{tabular}{|c|c|c|c|c|c|c|c|c|c|}
\hline \multirow{2}{*}{ 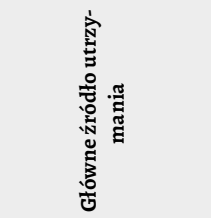 } & \multirow[b]{2}{*}{ 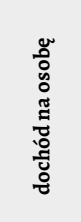 } & \multicolumn{8}{|c|}{ Wydatki na osobę } \\
\hline & & हूँّ & 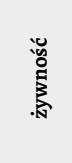 & 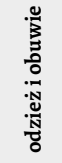 & 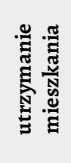 & 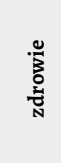 & 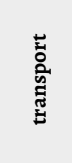 & 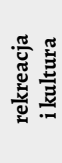 & 茕 \\
\hline $\begin{array}{l}\text { praca najemna na sta- } \\
\text { nowisku robotniczym }\end{array}$ & 1554,92 & 990,71 & 281,71 & 37,98 & 191,34 & 48,00 & 95,81 & 43,03 & 292,85 \\
\hline $\begin{array}{c}\text { praca najemna } \\
\text { na stanowisku } \\
\text { nierobotniczym }\end{array}$ & 2310,98 & 1506,96 & 348,78 & 70,83 & 259,09 & 83,54 & 178,66 & 56,37 & 509,69 \\
\hline
\end{tabular}




\begin{tabular}{|c|c|c|c|c|c|c|c|c|c|}
\hline \multirow{2}{*}{ 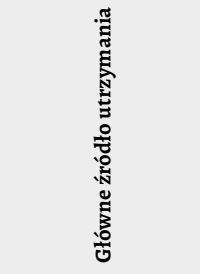 } & \multirow{2}{*}{ 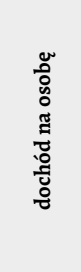 } & \multicolumn{8}{|c|}{ Wydatki na osobę } \\
\hline & & $\begin{array}{l}\text { E } \\
\text { : } \\
\text { : } \\
0\end{array}$ & 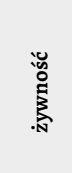 & 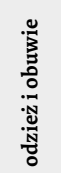 & 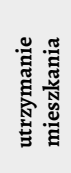 & 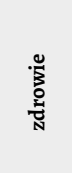 & 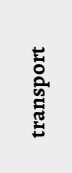 & 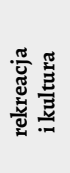 & 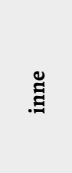 \\
\hline $\begin{array}{l}\text { użytkowanie gospo- } \\
\text { darstwa rolnego }\end{array}$ & 1717,60 & 881,40 & 278,50 & 43,55 & 134,18 & 51,97 & 100,43 & 35,91 & 236,86 \\
\hline $\begin{array}{c}\text { praca na własny } \\
\text { rachunek poza go- } \\
\text { spodarstwem rolnym } \\
\text { w użytkowaniu } \\
\text { indywidualnym, wy- } \\
\text { konywanie wolnego } \\
\text { zawodu }\end{array}$ & 2293,26 & 1452,13 & 346,99 & 69,39 & 258,77 & 84,50 & 157,82 & 56,50 & 478,17 \\
\hline emerytura & 1811,92 & 1375,63 & 380,22 & 40,03 & 301,57 & 117,82 & 91,34 & 49,92 & 394,74 \\
\hline renta & 1602,15 & 1318,30 & 387,05 & 30,47 & 319,69 & 118,85 & 41,23 & 50,53 & 370,46 \\
\hline
\end{tabular}

Źródło: obliczenia własne na podstawie danych в BGD z 2018 roku.

Zdecydowanie najlepszą sytuacją dochodową charakteryzują się te gospodarstwa, które utrzymują się z pracy na własny rachunek, natomiast najniższą gospodarstwa utrzymujące się przede wszystkim z renty. Warto zwrócić uwagę na wysoką wartość wydatków żywnościowych w tych gospodarstwach, co przy niskim poziomie wydatków ogółem daje wysoką wartość wskaźnika wydatków żywnościowych (29\%). Podobnie wydatki na utrzymanie mieszkania oraz na zdrowie w gospodarstwach utrzymujących się z renty są najwyższe, co pogłębia trudną sytuację ekonomiczną tych gospodarstw. W sumie relatywnie sztywne wydatki stanowią tu blisko 63\% ogółu wydatków.

W tabeli 9 pokazano zróżnicowanie dochodów i wydatków badanej grupy gospodarstw domowych ze względu klasę miejscowości zamieszkania gospodarstwa domowego osób starszych. 
Tabela 9. Dochody i wydatki gospodarstw domowych osób starszych w 2018 roku w układzie ze względu na klasę miejscowości w 2018 roku

\begin{tabular}{|c|c|c|c|c|c|c|c|c|c|}
\hline \multirow{2}{*}{ 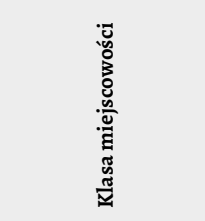 } & \multirow[b]{2}{*}{ 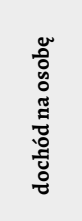 } & \multicolumn{8}{|c|}{ Wydatki na osobę } \\
\hline & & 离 & 瓷 & 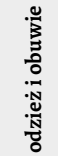 & 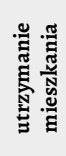 & 䒿 & 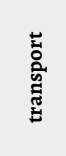 & 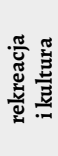 & 志 \\
\hline $\begin{array}{l}500 \text { tys. mieszkańców } \\
\text { i więcej }\end{array}$ & 2275,75 & 1632,11 & 390,67 & 51,37 & 336,99 & 144,46 & 125,68 & 61,44 & 521,49 \\
\hline $\begin{array}{l}\text { 200-499 tys. } \\
\text { mieszkańców }\end{array}$ & 2133,25 & 1651,35 & 396,98 & 51,56 & 336,37 & 128,57 & 157,95 & 67,04 & 512,90 \\
\hline $\begin{array}{l}\text { 100-199 tys. } \\
\text { mieszkańców }\end{array}$ & 2022,27 & 1473,98 & 379,71 & 50,30 & 305,81 & 121,60 & 105,17 & 55,31 & 456,08 \\
\hline $\begin{array}{l}20-99 \text { tys. } \\
\text { mieszkańców }\end{array}$ & 1875,86 & 1345,09 & 368,69 & 41,45 & 296,42 & 108,16 & 81,92 & 53,37 & 395,08 \\
\hline $\begin{array}{l}\text { poniżej } 20 \text { tys. } \\
\text { mieszkańców }\end{array}$ & 1768,22 & 1253,10 & 358,33 & 42,07 & 284,16 & 93,56 & 70,04 & 44,70 & 360,25 \\
\hline wieś & 1529,14 & 1102,83 & 331,73 & 38,33 & 220,61 & 76,91 & 95,23 & 38,34 & 301,69 \\
\hline
\end{tabular}

Źródło: obliczenia własne na podstawie danych BBGD z 2018 roku.

W przypadku podziału badanych gospodarstw domowych ze względu na klasę miejscowości zamieszkania można zauważyć, że dochody i wydatki spadają wraz ze spadkiem wielkości miejscowości. Ponadto w przypadku poszczególnych kategorii wydatków ich spadek jest mniej więcej proporcjonalny do spadku poziomu przeciętnych dochodów, chociaż wskaźnik wydatków żywnościowych rośnie wraz ze spadkiem wielkości miejscowości z poziomu 24\% dla największych miast do 30\% dla gospodarstw zamieszkujących na wsi.

W tabeli 10 pokazano natomiast dochody i wydatki gospodarstw osób starszych ze względu na wybrane kategorie typu biologicznego gospodarstwa. Dobór tych kategorii był analogiczny jak w przypadku rodzaju głównego źródła utrzymania i odnosił się do tych typów, dla których częstość ich występowania przekroczyła 1\% (zob. tabela 4). 
Tabela 10. Dochody i wydatki gospodarstw domowych osób starszych w 2018 roku w układzie ze względu na wybrany typ biologiczny gospodarstwa.

\begin{tabular}{|c|c|c|c|c|c|c|c|c|c|}
\hline \multirow[b]{2}{*}{ 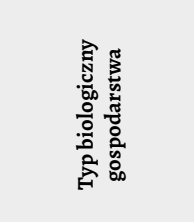 } & \multirow[b]{2}{*}{ 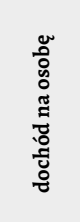 } & \multicolumn{8}{|c|}{ Wydatki na osobę } \\
\hline & & 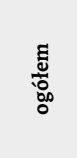 & 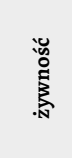 & 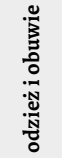 & 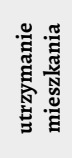 & 范 & 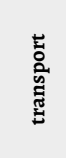 & 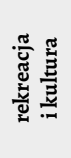 & 苂 \\
\hline $\begin{array}{c}\text { małżeństwo bez } \\
\text { dzieci }\end{array}$ & 1998,50 & 1454,77 & 390,29 & 47,14 & 288,49 & 119,93 & 132,20 & 52,20 & 424,52 \\
\hline $\begin{array}{l}\text { małżeństwo z przy- } \\
\text { najmniej } 1 \text { dziec- } \\
\text { kiem na utrzymaniu } \\
\text { i innymi osobami }\end{array}$ & 1350,64 & 822,48 & 233,06 & 44,44 & 134,61 & 40,92 & 88,22 & 36,27 & 244,96 \\
\hline $\begin{array}{l}\text { matka z dziećmi } \\
\text { na utrzymaniu } \\
\text { i innymi osobami }\end{array}$ & 1223,89 & 839,38 & 242,31 & 40,73 & 155,40 & 47,27 & 60,89 & 39,66 & 253,12 \\
\hline $\begin{array}{l}\text { gospodarstwa } \\
\text { jednoosobowe }\end{array}$ & 1962,82 & 1639,63 & 441,02 & 43,81 & 404,32 & 142,68 & 67,61 & 58,20 & 481,99 \\
\hline pozostałe & 1712,08 & 1081,84 & 307,31 & 35,85 & 215,16 & 71,75 & 88,23 & 42,94 & 320,61 \\
\hline
\end{tabular}

Źródło: obliczenia własne na podstawie danych B BGD z 2018 roku.

Zdecydowanie w najlepszej sytuacji dochodowej są gospodarstwa małżeństw bez dzieci i gospodarstwa jednoosobowe. W przypadku tych pierwszych - można przypuszczać - mamy do czynienia najczęściej z dwójką starszych osób, natomiast w przypadku gospodarstwa jednoosobowego badana osoba jest wieku co najmniej 6o lat (takie zostało przyjęte założenie przy prezentowanych badaniach). W tym drugim przypadku odnotowujemy zdecydowanie najwyższy poziom wydatków żywnościowych, wydatków na utrzymanie mieszkania czy zdrowie. Wynika to z braku efektu skali, który odnosi się do gospodarstw wieloosobowych, w których następuje redukcja poziomu wydatków na osobę w odniesieniu do wydatków w dużej mierze 
niezależnych od liczby osób, jakimi są np. wydatki na utrzymanie mieszkania. $Z$ tego powodu pomimo relatywnie wysokiego poziomu przeciętnych dochodów gospodarstwa jednoosobowe są w gorszej sytuacji ekonomicznej niż gospodarstwa $\mathrm{z}$ dwiema dorosłymi osobami. Przypuszczenie to znajduje potwierdzenie w wynikach zaprezentowanych w tabeli 11, w której gospodarstwa jednoosobowe mają zdecydowanie największe wydatki na osobę na żywność, utrzymanie mieszkania oraz zdrowie.

Tabela 11. Dochody i wydatki gospodarstw domowych osób starszych w 2018 roku w układzie ze względu na liczbę osób w gospodarstwie domowym

\begin{tabular}{|c|c|c|c|c|c|c|c|c|c|}
\hline \multirow[b]{2}{*}{ 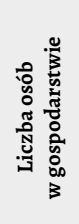 } & \multirow[b]{2}{*}{ 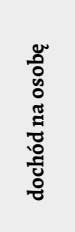 } & \multicolumn{8}{|c|}{ Wydatki na osobę } \\
\hline & & 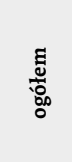 & $\begin{array}{l}\text { 诘 } \\
\text { 胥 } \\
\text {. }\end{array}$ & 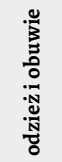 & 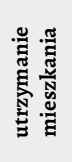 & 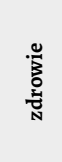 & 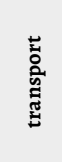 & 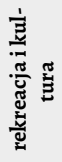 & . \\
\hline 1 & 1962,82 & 1639,63 & 441,02 & 43,81 & 404,32 & 142,68 & 67,61 & 58,20 & 481,99 \\
\hline 2 & 1954,14 & 1417,54 & 382,94 & 45,79 & 284,50 & 115,63 & 123,97 & 51,42 & 413,29 \\
\hline 3 & 1738,39 & 1115,96 & 310,64 & 38,05 & 217,13 & 71,79 & 98,32 & 43,68 & 336,35 \\
\hline 4 & 1561,23 & 952,45 & 270,02 & 40,00 & 168,70 & 54,53 & 85,52 & 41,82 & 291,84 \\
\hline$\stackrel{5}{5}$ i więcej & 1337,82 & 803,62 & 230,39 & 42,18 & 134,08 & 40,58 & 83,29 & 35,42 & 237,67 \\
\hline
\end{tabular}

Źródło: obliczenia własne na podstawie danych в вGD z 2018 roku.

W dwóch ostatnich tabelach (12 i 13) przedstawiono dochody i wydatki gospodarstw z osobami starszymi ze względu na ich stan cywilny, jak i poziom wykształcenia. Najwyższymi dochodami na osobę charakteryzują się gospodarstwa tych osób starszych, które są po rozwodzie, a następnie osób pozostających w związku małżeńskim, 
chociaż zasadniczo nie obserwujemy tak dużych różnic w przeciętnych poziomach badanych dochodów i wydatków, jak to miało miejsce w przypadku innych przekrojów analizowanej zbiorowości. Natomiast takie zróżnicowanie jest obecne w podziale gospodarstw ze względu na wykształcenie osoby starszej. Wraz ze wzrostem poziomu wykształcenia zdecydowanie wzrastają przeciętne dochody na osobę, jak i wydatki ogółem oraz wydatki dla kolejnych kategorii towarów i usług. Pomimo wysokich wydatków na żywność w gospodarstwach osób starszych $\mathrm{z}$ wyższym wykształceniem ich udział w wydatkach ogółem wynosi $21,6 \%$, podczas gdy w przypadku osób z najniższym poziomem wykształcenia $31,5 \%$. Wyniki te są wprost przeniesieniem sytuacji ekonomicznej osób z różnymi poziomami wykształcenia w czasie ich aktywności zawodowej, kiedy to wykształcenie jest główną determinantą poziomu płac.

Tabela 12. Dochody i wydatki gospodarstw domowych osób starszych w 2018 roku w układzie ze względu na stan cywilny

\begin{tabular}{|c|c|c|c|c|c|c|c|c|c|}
\hline \multirow{2}{*}{ 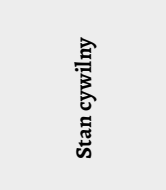 } & \multirow{2}{*}{ 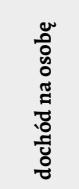 } & \multicolumn{8}{|c|}{ Wydatki na osobę } \\
\hline & & 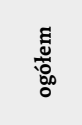 & 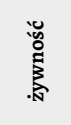 & 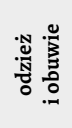 & 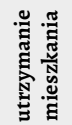 & & 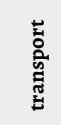 & 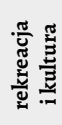 & : \\
\hline kawaler, panna & 1766,67 & 1342,60 & 367,29 & 48,31 & 286,15 & 105,79 & 62,75 & 51,26 & 421,05 \\
\hline żonaty, zamężna & 1852,04 & 1285,94 & 351,05 & 43,69 & 249,83 & 97,86 & 118,23 & 47,96 & 377,31 \\
\hline wdowiec, wdowa & 1754,98 & 1343,61 & 369,93 & 39,97 & 315,81 & 109,79 & 69,58 & 49,81 & 388,73 \\
\hline $\begin{array}{l}\text { rozwiedziony, } \\
\text { rozwiedziona }\end{array}$ & 1998,00 & 1622,15 & 407,89 & 57,34 & 369,65 & 117,55 & 93,57 & 62,13 & 514,02 \\
\hline w separacji & 1797,97 & 1437,71 & 426,87 & 46,64 & 313,68 & 86,76 & 63,78 & 50,31 & 449,67 \\
\hline
\end{tabular}

Źródło: obliczenia własne na podstawie danych в вGD z 2018 roku. 
Tabela 13. Dochody i wydatki gospodarstw domowych osób starszych w 2018 roku w układzie ze względu na wykształcenie

\begin{tabular}{|c|c|c|c|c|c|c|c|c|c|}
\hline \multirow[b]{2}{*}{ 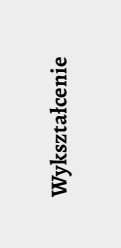 } & \multirow[b]{2}{*}{ 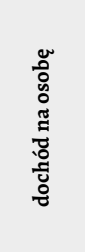 } & \multicolumn{8}{|c|}{ Wydatki na osobę } \\
\hline & & 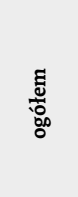 & 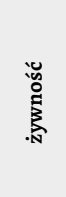 & 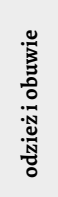 & 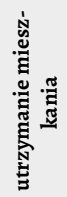 & 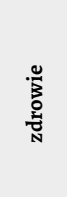 & 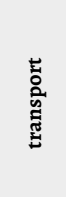 & 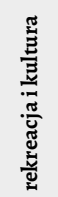 & $\Xi$ \\
\hline $\begin{array}{l}\text { co najwyżej } \\
\text { gimnazjalne }\end{array}$ & 1429,13 & 1002,24 & 315,76 & 30,18 & 221,44 & 76,82 & 58,73 & 35,27 & 264,05 \\
\hline $\begin{array}{l}\text { zasadnicze } \\
\text { zawodowe }\end{array}$ & 1620,29 & 1155,04 & 341,18 & 36,96 & 251,26 & 81,54 & 81,26 & 43,62 & 319,23 \\
\hline średnie & 1944,20 & 1446,72 & 383,59 & 47,92 & 308,78 & 114,20 & 108,14 & 55,17 & 428,92 \\
\hline wyższe & 2734,63 & 1992,29 & 431,07 & 71,39 & 364,63 & 170,46 & 196,01 & 74,14 & 684,59 \\
\hline
\end{tabular}

Źródło: obliczenia własne na podstawie danych B BGD z 2018 roku.

\section{Podsumowanie}

Wyniki prognoz demograficznych jednoznacznie przedstawiają dynamiczny wzrost liczby ludności w starszym wieku, obrazując proces starzenia się społeczeństwa w niedalekiej przyszłości. Osoby starsze często uzależnione są od otoczenia, a ta zależność może być skutkiem większej chorobliwości lub specyficznych przypadłości dotykających te osoby. Skala i rozwój potrzeb tej grupy społecznej jest zróżnicowana, co za tym idzie - konsekwencje społeczno-ekonomiczne również ulegają znaczącym zmianom. Wśród obszarów kryzysowych należy wymienić m.in. sytuację ekonomiczną (poziom zdolności zarobkowania bądź obniżenie statusu majątkowego), społeczną (potrzeby przynależności, aktywności i potrzeby kulturalne), psychologiczną (związane z potrzebami emocjonalnymi i duchowymi), oraz funkcjonalną (czynności dnia codziennego i opieką). Należy podkreślić, 
że nastąpi: (1) wzrost kosztów z powodu zwiększonego zatrudnienia pracowników odpowiedzialnych za opiekę nad seniorami, (2) wzrost liczby miejsc pracy dla odpowiednio wykwalifikowanego personelu, (3) zwiększenie się zapotrzebowania na świadczenia pieniężne wśród potrzebujących seniorów, (4) konieczność modernizacji, zmiany struktury, doposażenia miejsc realizacji usług kierowanych do osób starszych.

W artykule przyjęto definicję osoby starszej jako osoby mającej 60 lat i więcej, opracowano i porównano dla tej grupy wiekowej dane statystyczne, charakteryzując pokrótce rozmieszczenie osób starszych w poszczególnych województwach (najwięcej woj. mazowieckie $-13,42 \%$, najmniej woj. lubuskie $-2,42 \%$ ), przedstawiono strukturę głównych źródeł utrzymania, pokazując, że największą część dochodu uzyskiwano w gospodarstwach osób starszych ze świadczeń emerytalnych - 64,34\%, a najmniej bo - 0,17\% - z własności. Ciekawym porównaniem stało się również przedstawienie struktury osób starszych w klasach miejscowości zamieszkania. Jak wynika z badania, największy udział procentowy seniorów odnotowany w 2018 roku był na wsiach i wynosił 35,16\%, a najniższy w miastach - 8,97\% - zamieszkiwanych przez 100-199 tys. mieszkańców. Warto podkreślić, że najwięcej osób starszych określało się statusem osób pozostających w związkach małżeńskich - 59,9\%.

Wyniki wskazują, że w latach 2010-2018 dynamicznie wzrastały dochody $z$ emerytur. Przedstawiono strukturę wydatków gospodarstw domowych, w których głównym źródłem utrzymania była emerytura zarówno dla gospodarstw domowych jednoosobowych, jak i wieloosobowych. W obydwu przypadkach obserwuje się wzrost wydatków ogółem, odpowiednio ok. 18,3\% i 19,5\%. Najczęściej środki finansowe przeznaczane są na zakup żywności, opłacenie mieszkania i bardzo ważne z punktu widzenia utrzymania zdrowia wydatki na zdrowie sięgające 9\% ogółu wydatków. Najwyższy dochód na osobę w roku 2018 
odnotowany został w województwie mazowieckim - 2087,18 zł, natomiast wydatki ogółem na jedną osobę starszą również w tym województwie wyniosły 1533,57 zł. Najniższy dochód odnotowano w województwie podkarpackim - 1518,68 zł, a wydatki wyniosły 1065,85 zł.

Jeżeli uwaga zostanie skupiona na poziomie dochodów gospodarstw domowych osób starszych w układzie ze względu na wybrane główne źródło utrzymania, to w roku 2018 w największą kwotę - 2310,98 zł - odnotowano w przypadku gospodarstw głównie utrzymujących się z pracy najemnej na stanowisku nierobotniczym, w przypadku których ogółem wydatki stanowiły 1506,96zł, w tym wydatki na zdrowie pochłonęły 83,54 zł. Natomiast dochód w gospodarstwach utrzymujących się głównie $z$ emerytury i renty wynosił odpowiednio 1811,92 zł i 1602,15 zł. Warto podkreślić, że dochody osób starszych nie różnią się znacząco, jeśli rozpatruje się je pod względem tego, czy jest to gospodarstwo jedno czy dwuosobowe, bowiem dochód na osobę w gospodarstwie jednoosobowym wynosił 1962,82 zł, a w dwuosobowym 1954,14 zł.

Zaprezentowane wyniki badania sytuacji ekonomicznej gospodarstw domowych osób starszych pokazują, że sytuacja ta poprawia się, chociaż jest znacząco zróżnicowana ze względu na różne grupy społeczne.

\section{Streszczenie}

Globalne zmiany demograficzne dotyczące zarówno Polski, jak i innych krajów świata, stanowią przedmiot badań wielu dziedzin nauki. Wzrost odsetka ludności w wieku starszym to przyczyna wielu przemian gospodarczych kraju, które prowadzą do coraz to nowych konsekwencji społeczno-ekonomicznych. Celem artykułu jest przedstawienie sytuacji ekonomicznej gospodarstw domowych, w których żyją osoby starsze. W części metodologicznej przedstawione zostało zjawisko starzenia się. Tam też wyodrębniono najważniejsze jego konsekwencje wpływające zarówno na społeczeństwo, jak i sytuację ekonomiczną państwa. Określono również i dostosowano do analizowanego 
problemu definicję seniora. W części empirycznej przedstawione zostały dochody i wydatki gospodarstwach domowych osób starszych. Zaprezentowano ich dynamikę, przeanalizowano główne źródła utrzymania oraz wskazano, jak się one kształtują w zależności od stanu cywilnego, wykształcenia czy liczby osób zamieszkujących dane gospodarstwo domowe osób starszych.

Słowa kluczowe: sytuacja ekonomiczna seniorów, starzenie się populacji, gospodarstwa domowe osób starszych, bezpieczeństwo bytu na starość, dochody i wydatki gospodarstw domowych

\section{Summary}

Households of the elderly and their economic situation

Global demographic changes concerning Poland and other countries of the world are the subject of research in many fields of science. The increase in the percentage of the elderly population is the cause of many economic changes in the country, which lead to new socio-economic consequences. The aim of the article is to present the economic situation of households in which elderly people live. The methodological part presents the phenomenon of aging. There, the most important consequences affecting the society and the economic situation of the state were identified. The definition of a senior was also defined and adjusted to the analysed problem. The empirical part presents the income and expenditure of households of the elderly. Their dynamics were presented, the main sources of income were analysed and it was indicated how they are shaped depending on marital status, education or the number of people living in a given household of elderly people.

Keywords: economic status of seniors, population aging, households of the elderly, security of existence in old age, household income and expenses 
